\title{
Analysis of the Clinicopathological Features and Prognosis of Pregnancy with Gastric Cancer: A Case- Control Study
}

\section{Ying Han}

Beijing Chaoyang Hospital https://orcid.org/0000-0002-2759-5425

Junli Lu

Beijing Chaoyang Hospital

Lei Zhu

Beijing Chaoyang Hospital

Cuiqin Sang

Beijing Chaoyang Hospital

ShuZhen Wang ( $\sim$ darrywang2003@163.com )

\section{Research article}

Keywords: Gastric Cancer, Pregnancy, Clinical manifestations, Prognosis

Posted Date: July 21st, 2020

DOI: https://doi.org/10.21203/rs.3.rs-32729/v1

License: (c) (i) This work is licensed under a Creative Commons Attribution 4.0 International License. Read Full License 


\section{Abstract}

Background

To summarize the clinicopathological features and prognostic factors of pregnancy with gastric cancer.

Methods

The clinical data of pregnant patients with gastric cancer diagnosed and treated in our hospital from 2009.1 to 2019.12 were analyzed. Two sex-, age-, and stage- matched controls for each case were identified from the medical data. Clinical characteristics, pathological features and prognosis were summarized.

Results

The median overall survival time of the pregnancy with gastric cancer and the control group were 8.0 months and 11.0 months, respectively $(P=0.05)$. The advanced stage was associated with poor prognostic factors. Pregnancy with gastric cancer was associated with a longer time from diagnosis to treatment ( 19.0 days vs 9.0 days, $p=$ $0.012)$. The median age was 32 years old ( $26.0 \otimes 41.0$ years old). The diagnosed time of prengnancy week was 9.0 $\sim 37.0$ weeks. Of 22 patients, 4 patients had gastric cancer family history. Abdominal pain (6/22, 27.3\%) was the most common presentation, and other symptoms were nausea and/or vomiting $(3 / 22,13.6 \%)$, nonspecific dyspepsia ( 3 cases, $13.6 \%$ ), and melena (1 case, $4.5 \%$ ). Other 9 patients ( $41.0 \%$ ) were identified with metastatic features, including abdominal distention, ascites, abdominal mass, and jaundice. 5 cases $(22.7 \%)$ received curative gastrectomy, 5 patients $(22.7 \%)$ received chemotherapy,and other 12 patients (54.6\%) received supportive therapy.

Conclusions

The prognosis of patients with gastric cancer in pregnancy is very poor, and patients often cannot be diagnosed in time. The tumor differentiation is poor with advanced stage, always progresses rapidly with high mortality. And the tumor stage was the significant factor influecing the prognosis.

\section{Background}

Gastric cancer is a leading cause of cancer-related mortality world-wide, especially in Asian countries [1].

Pregnancy with gastric cancer is rare to see, accounting for only $0.016 \%$ to $0.09 \%$ of all pregnancies [2]. However, gastric cancer diagnosed during pregnancy is serious that endangers both the mother and the fetus with really bad prognosis. The reason may be that most patients are diagnosed at advanced stage and only $40 \%$ patients have operation opportunity when diagnosed [3].

The clinical features, diagnosis and treatment are all different from normal gastric cancer. It is reported that about $80 \%$ patients were advanced stage at the time of diagnosis, and the mortality rate was as high as $99 \%$ [4]. The survival rate of females with gastric cancers, especially pregnancy, was lower than males. And it suggested that hormonal may influence the characteristic of gastric cancers. Studies showed that all patients with pregnancyassociated gastric cancers died within 9 to 19 months after diagnosis[5]. Due to the influence of pregnancy factors, the misdiagnosis rate of pregnancy with gastric cancer is high, which is worthy of clinicians' attention. 
In this study, we used the contral case with each pregnancy patient in gastric cancers to analyze the clinicopathological features and prognosis by reviewing case data and literature review, in order to provide references for future clinical diagnosis and treatment.

\section{Methods}

\section{General Data Of Patients}

All patients diagnosed as gastric cancer that presented to our institution between Janury 2009 and December 2019 were identified by reviewing medical database. Patients who diagnosed with pregnancy-associated gastric carcinoma were the case group of this study. We collected their medical informatiom including obstetrics state, endoscopic records, clinical treantment, and outcome of gastric cancer. And we sought two factor matched control cases for each patients of case group. In total, there was 44 controls.

\section{Statistical analysis}

Fisher exact test was used in the case and control groups on the categorical, and Mann-Whitney $U$ test was used in continuous variables using. Kaplan-Meier method was used to caculate cumulative survival. The survical difference between two groups was determined by the log-rank test. The relationship between clinicopathological factors and survival was identified by the Cox proportional hazard regression analysis. Of all the data, $p$-values less than 0.05 were considered to be statistical significant. All data analyses were using IBM SPSS version 22.0.

\section{Results}

\section{General Features and Clinical Presentation}

During Janury 2009 to December 2019, a total of 6871 patients were diagnosed with gastric cancer in our hospital, of which, $22(0.32 \%)$ were with prengnancy. Their median age was 32 years ( 26.0 to 41.0 years). All the patients were diagnosed with gastric cancer during pregnancy period. And the median gestational age at diagnosis was 27 weeks ( 9.0 to 37.0 weeks). Of 22 patients, 4 patients had gastric cancer family history. Abdominal pain $(6 / 22,27.3 \%)$ was the most common presentation, and other symptoms were nausea and/or vomiting (3/22, 13.6\%) , nonspecific dyspepsia (3 cases, 13.6\%), and melena (1 case, 4.5\%). Other 9 patients $(41.0 \%)$ were identified with metastatic features, including ascites, abdominal distention, jaundice and abdominal mass .

\section{Treatment and Survival}

Of the 22 patients, 5 cases(22.7\%) received curative gastrectomy, 5 patients $(22.7 \%)$ received chemotherapy $₫$ and other 12 patients (54.6\%) received supportive therapy. Of all 22 patients, the median survival time was 8.0 months ( 2.3 to 25.8 months).

As to the patients who received different therapy, the survival time was 30.5 months (20.4 to 74.0 months) of those who received gastrectomy, 5.2 months ( 0.8 to 6.4 months) of those who received chemotherapy and 1.6 months ( 0.7 to 11.5 months) for that only received supportive treatment. Of all the patients, the median interval time from the onset of symptoms to diagnosis was 75.4 days (28 to 139 days), and the time from pathological diagnosis to treatment was 19 days (8.0 to 29.0 days). 


\section{Obstetrics Outcome}

Of the 22 patients, 14 patients (63.6\%) terminated the pregnancy. And the median termination age was 13.0 weeks ( 9.0 to 22.0 weeks). The remaining 8 patients received cesarean section, and the median operated time was 34.2 weeks (28.0 to 36.0 weeks). Of all the patients, there was no obstetric complications or fetal metastasis. Microscopic placental metastasis was found in two patients. The clinical features and outcomes of the case group is summarized in Table 1.

\section{The Clinicopathological Features of Gastric Cancers}

In order to analyze the factors that associated with the prognosis of pregnency with gastric cancer, we used case contral by matching two gastric cancer patients without pregnancy. The characteristic factors of the case group and control group are summarized in Table2.

From the table we can see that in the contral group, median overall survival time was 11.0 month, three month longer than in case group $(\mathrm{P}=0.05)$. As to the clinical presentation, abdominal pain was the most common in case group while dyspepsia in control group $(p=0.087)$. On the tumor location, it was amost equal to see in antrum, corpus, and entire stomach of the case group, while in the contral group the corpus was the most (72.7\%). In both groups the gastric cancers were mostly advanced, and the stage IV were $81.8 \%$ in the case and $93.2 \%$ in the contral group, respectively. On the treatment, there was $22.7 \%$ and $25 \%$ percent patients received curative gastrectomy, $22.7 \%$ and $22.7 \%$ of the case and control group patients received chemotherapy. Almost all patients of the two group were signet ring cell carcinomas or poorly differentiated.

\section{Prognosis Related Factors}

In order to identify the factors that associated with survival, we analyze the case group and the case plus control cohort. Of all the factors, age, tumor stage, diagnosis period, tumor location, were analyzed. In the case group, stage IV $(p=0.048)$, tumor involved the entire stomach $(p=0.022)$ were associated with the highest risk of death. However, age, pregnancy week,treatment and other factors had no relationship with the overall survival .

Of the cases plus controls cohort, all the factors were analyzed using the same method The result showed that the tumor stage had significant influence to prognosis $(p<0.001)$. And the tumor location was associated significantly with a poor prognosis, while the corpus location had a $p$ value $=0.045$ and the entire stomach had a $p$ value $=0.021$. Other factors such as age, pregnancy week,treatment and other factors had no relationship with prognosis.

\section{Discussion}

Although gastrointestinal malignancy in pregnancy is rare, the mortality rate of pregnant women is extremely high. There are mostly reports of individual cases worwide, among which gastric cancer is the most common, and pancreatic cancer and liver cancer are also reported.

Studies have found that the incidence of gastric cancer in young women is higher than that in young men, and the degree of malignancy is higher and the prognosis is worse [6]. Therefore, it is generally believed that female hormones have a certain influence on the occurrence and development of the tumor. Gastrointestinal malignancy 
develops rapidly after pregnancy, and it may be that the specific physiological state of pregnancy changes the biological behavior of the tumor.

Pregnancy associated with gastric cancer is difficult to diagnose in early stage, which may be due to the following reasons[7]. Firstly, clinical manifestations of patients with gastric cancer during early pregnancy are often not specific, such as nausea, vomiting, abdominal discomfort, appetite loss, fatigue, dyspnea and accelerated heart rate, which are often confused with the pregnancy reaction, and are easy to cover up the manifestations of gastric cancer and easy to be ignored. Secondly, progesterone is increased in early pregnancy, gastric acid secretion is reduced, histamine is inactivated by histaminase produced by placenta, and the risk of ulcer is reduced, which may also mask the clinical symptoms of gastric cancer. Thirdly, the intraperitoneal metastasis of advanced gastric cancer, such as ascites is easlly be ignored because of the abdominal pelvic swelling during pregnancy. In addition, for worring about the influence of some auxiliary examinations such as the commonly used abdominal and pelvic CT examinationmay to affect the fetus, many patients missed the opportunity of early diagnosis. Based on the above reasons, many patients could not be diagnosed in time. It is reported that $96.7 \%$ patients(59/61) of gastric cancer with pregnancy was diagnosed in advanced stage [8].

The main reason that the rapid development of pregnancy complicated with gastric cancer is not only the difficulty to diagnose in time, but also that the endocrine and immune functions during pregnancy change the biological behavior of gastric cancer. In addition, the imbalance of maternal cell immune regulation and the lack of blocking antibodies in the mother also create conditions for the occurrence and development of tumor cells [9]. Another factor is the pathology type, low differentiated adenocarcinoma and signet ring cell carcinoma is the major type during pregnancy[10], with high malignant degree and poor differentiation, and always with transfer to peritoneal, retroperitoneal lymph nodes and ovarian [11]. Relative to the intestinal type of gastric cancer, diffuse gastric cancer are far more common in patients with ovarian metastasis [12]. Diffuse gastric cancer is the most common type of pathology of poorly differentiated adenocarcinoma and signet ring cell carcinoma, which also conforms to the common pathological types of gastric cancer in pregnancy, so the tumor progresses very quickly, the prognosis is extremely poor, and the survival rate is very low [13]. In this study, the patients with pregnancy related gastric cancer had a poor prognosis with a 8 month median overall survival time. The result showed that worse prognosis was assaciated with advanced stage and the tumor location. In the case group, the median time from diagnosis to treatment was 19 days, longer than the control group with 9 days. The reason may be that the gastric cancer symptoms frequently overlap with pregnancy symptoms such as gastric discomfort and hyperemesis, which are easily to be ignored. What is more, patients always hesitate when faced with the fact that the treatment of the surgery or chemotherapy may influence the fetus.

The treatment principle for pregnancy with gastric cancer is to start the treatment as soon as diagnosis, and the treatment method is mainly based on the stage of gastric cancer and the pregnancy week [14]. For patients with late pregnancy, radical gastrectomy after vaginal delivery or cesarean section are currently recommended. For patients less than 28 weeks gestation, artificial termination of gestation combined with radical gastrectomy is recommended[15]. The choice of treatment strategy is still controversial for patients between the gestation period of 24 weeks and the third trimester, so it is suggested to formulate more appropriate treatment strategy according to individual situation. In the clinical work, once confirmed, most patients have no surgery opportunity. Palliative chemotherapy is the main treatment [16].

In order to improve the prognosis of gastric cancer in pregnancy, it is important to improve the early diagnosis rate and appropriate treatment. When facing pregncy patients with abnormal gastrointestinal symptoms, we should 
focus on the investigation of gastrointestinal malignant tumors. Combined with previous literature recommendations :(1) Having a family history of gastrointestinal tumor, gastroscopy before pregnancy is recommended; (2) Gastrointestinal reactions beyond the normal gestational week should be examined carefully in a timely manner; (3) Lumbosacral pain should be regarded as malignant tumor metastasis if it cannot be explained by common reasons; (4) Non-invasive or minimally invasive examinations can be performed during pregnancy for symptoms that cannot be explained by common reasons, such as tumor markers, ultrasound, magnetic resonance examination; (5) Special attention should be paid to abnormal gastrointestinal symptoms, and individualized comprehensive diagnosis and treatment should be emphasized to avoid missed diagnosis and misdiagnosis of such patients.

\section{Conclusion}

Early diagnosis of pregnancy complicated with gastric cancer is difficult, the clinical stage is advanced, the tumor malignancy is high, and prognosis is extremely poor. Early diagnosis and appropriate treatment is extremely important in clinical work.

\section{Abbreviations}

computed tomography (CT)

\section{Declarations}

\section{- Ethics approval and consent to participate}

Our study is a kind of retrospective study. All study procedures were approved by the ethics committee of the Beijing Chao-Yang Hospital, Capital Medical University (No.2019-354). We conducted research using identifiable electronic medical record data. The research project did not involve personal privacy and commercial interests and was no longer accessible to participants. Therefore, the ethics committee approved the waiver of signed written informed consent and approved the procedure for verbal consent. We retrospectively analyzed the medical data records. All patients in this study gave their verbal informed consent at the time of diagnosis that their medical records could be reviewed within the retrospective studies.

\section{- Consent for publication}

Not applicable.

\section{- Availability of data and materials}

The datasets used and/or analysed during the current study are available from the corresponding author on reasonable request.

\section{- Competing interests}

The authors declare that they have no competing interests.

\section{- Funding}


No funding in this manuscript.

\section{- Authors' Contributions}

YH and SZ W design of the work, YH was a major contributor in writing the manuscript and drafted the work and substantively revised it. JL $L$ has made substantial contributions to the conception. $L Z$ has made substantial contributions to the acquisition and analysis. CQ S has made substantial contributions to the interpretation of data. And all authors read and approved the final manuscript.

\section{- Acknowledgements}

Not applicable

\section{References}

1. Lee 1LeeHJ, Kim IK. JW,et al. Clinical characteristics of gastric cancer associated with pregnancy[J]. Dig Surg. 2009;26(1):31-6.

2. Park 2SongMJ, Song YS. HJ,et al. Prognosis of pregnancy-associated gastric cancer: an age-, sex-, and stagematched case-control study[J]. Gut Liver.2016 Sep 15;10(5): 731ه738.

3. 3..Chu HN. Clinical characteristics of gastric cancer during pregnancy andthe reasons for misdiagnosis[J]. Chin J Obstet Gynecol. 2003;38(11):701-2.

4. Gillessen 4AspersVK, Quakemack A. K,et al. Gastric cancer in pregnancy: do pregnancy,age or female sex alter the prognosis? Case reports and review[J]. Eur J Obstet Gynecol Reprod Biol. 1999;87:13-22.

5. Lee 5LeeHJ, Kim IK. JW,et al. Clinical characteristics of gastric cancer associated with pregnancy[J]. Dig Surg. 2009;26(1):31-6.

6. Refaie 6Al-, Hu WB, Pisters CY. PW,et al.Gastric adenocarcinoma in young patients: a population-based appraisal. Ann Surg Oncol. 20110ct;18(10):2800-7.

7. Kanda 7SakamotoK, Ohashi T. M, et al. Management of patients with pregnancy-associated gastric cancer in Japan: a mini-review. Int J Clin Oncol. 2009 Oct;14(5):392-6.

8. Matsuoka $8 \mathrm{UeoH}$, Tamura H. S,et al.Prognosis in gastric cancer associated with pregnancy. World J Surg. 1991;15:293-7.

9. Takeda 9Kodamal, Koufuji J. K,et al.Gastric cancer during pregnancy. Kurume Med J. 1997;44:179-83.

10. Choi 10SuhM, Lee KS. YY, et al. Cancer screening in Korea, 2012: results from the Korean National Cancer Screening Survey. Asian Pac J Cancer Prev. 2013;14:6459-63.

11. Kim 11LaiJF, Li S. C, et al. Clinicopathologic characteristics and prognosis for young gastric adenocarcinoma patients after curative resection. Ann Surg Oncol. 2008;15:1464-9.

12. Takaya 12SaitoH, Fukumoto S. Y,et al. Clinicopathologic characteristics and prognosis of gastric cancer in young patients. Yonago Acta Med. 2012;55:57-61.

13. Hashimoto 13lsobeT, Kizaki K. J, et al. Characteristics and prognosis of gastric cancer in young patients. Oncol Rep. 2013;30:43-9.

14. Gandra 14TavaresA, Viveiros A. F, et al. Analysis of clinicopathologic characteristics and prognosis of gastric cancer in young and older patients. Pathol Oncol Res. 2013;19:111-7. 
15. Ahn 15ParkHJ, Jung JY. HY, et al. Clinical characteristics and outcomes for gastric cancer patients aged 1830 years. Gastric Cancer. 2014;17:649-60.

16. Eom 16OhHS, Kang DW. GH, et al. Prognostic implications of EGFR and HER-2 alteration assessed by immunohistochemistry and silver in situ hybridization in gastric cancer patients following curative resection. Gastric Cancer. 2014;17:402-11.

\section{Tables}

Table 1. clinical features and outcomes of pregnancy with gastric cancer 


\begin{tabular}{|c|c|c|c|c|c|c|c|c|c|}
\hline \multirow[t]{2}{*}{ No. } & \multirow[t]{2}{*}{ Age } & \multirow[t]{2}{*}{ Week } & \multirow{2}{*}{$\begin{array}{l}\text { Family } \\
\text { history }\end{array}$} & \multirow[t]{2}{*}{ Presentation } & \multirow[t]{2}{*}{ outcome } & \multirow[t]{2}{*}{ Stage } & \multirow[t]{2}{*}{ Treatment } & \multicolumn{2}{|c|}{ Survival outcome } \\
\hline & & & & & & & & survival & infant \\
\hline 1 & 26 & 9 & Y & dyspepsia & Termination & IV & Gastrectomy & Death & Death \\
\hline 2 & 27 & 12 & $\mathrm{~N}$ & $\begin{array}{l}\text { abdominal } \\
\text { pain }\end{array}$ & Termination & IV & Chemotherapy & Death & Death \\
\hline 3 & 27 & 28 & $\mathrm{~N}$ & $\begin{array}{l}\text { nausea } \\
\text { and/or } \\
\text { vomiting }\end{array}$ & $\begin{array}{l}\text { Cesarean } \\
\text { section }\end{array}$ & IV & Chemotherapy & Death & Alive \\
\hline 4 & 28 & 34 & $\mathrm{~N}$ & dyspepsia & $\begin{array}{l}\text { Cesarean } \\
\text { section }\end{array}$ & IV & Gastrectomy & Death & Alive \\
\hline 5 & 28 & 35 & Y & $\begin{array}{l}\text { abdominal } \\
\text { distention }\end{array}$ & $\begin{array}{l}\text { Cesarean } \\
\text { section }\end{array}$ & IV & Chemotherapy & Death & Alive \\
\hline 6 & 27 & 28 & Y & $\begin{array}{l}\text { nausea } \\
\text { and/or } \\
\text { vomiting }\end{array}$ & $\begin{array}{l}\text { Cesarean } \\
\text { section }\end{array}$ & IV & Chemotherapy & Death & Alive \\
\hline 7 & 31 & 22 & $\mathrm{~N}$ & $\begin{array}{l}\text { abdominal } \\
\text { pain }\end{array}$ & Termination & IV & Chemotherapy & Death & Death \\
\hline 8 & 32 & 33 & Y & $\begin{array}{l}\text { abdominal } \\
\text { distention }\end{array}$ & $\begin{array}{l}\text { Cesarean } \\
\text { section }\end{array}$ & IV & $\begin{array}{l}\text { palliative } \\
\text { therapy }\end{array}$ & Death & Alive \\
\hline 9 & 32 & 13 & $\mathrm{~N}$ & dyspepsia & Termination & IV & $\begin{array}{l}\text { palliative } \\
\text { therapy }\end{array}$ & Death & Death \\
\hline 10 & 33 & 14 & $\mathrm{~N}$ & $\begin{array}{l}\text { abdominal } \\
\text { distention }\end{array}$ & Termination & IV & $\begin{array}{l}\text { palliative } \\
\text { therapy }\end{array}$ & Death & Death \\
\hline 11 & 34 & 32 & $\mathrm{~N}$ & $\begin{array}{l}\text { abdominal } \\
\text { pain }\end{array}$ & $\begin{array}{l}\text { Cesarean } \\
\text { section }\end{array}$ & IV & $\begin{array}{l}\text { palliative } \\
\text { therapy }\end{array}$ & Death & Alive \\
\hline 12 & 31 & 37 & $\mathrm{~N}$ & melena & $\begin{array}{l}\text { Cesarean } \\
\text { section }\end{array}$ & IV & $\begin{array}{l}\text { palliative } \\
\text { therapy }\end{array}$ & Death & Alive \\
\hline 13 & 32 & 21 & $\mathrm{~N}$ & $\begin{array}{l}\text { abdominal } \\
\text { pain }\end{array}$ & Termination & IV & $\begin{array}{l}\text { palliative } \\
\text { therapy }\end{array}$ & Death & Death \\
\hline 14 & 35 & 22 & $\mathrm{~N}$ & $\begin{array}{l}\text { abdominal } \\
\text { distention }\end{array}$ & Termination & 1 & $\begin{array}{l}\text { palliative } \\
\text { therapy }\end{array}$ & Death & Death \\
\hline 15 & 33 & 35 & $\mathrm{~N}$ & $\begin{array}{l}\text { nausea } \\
\text { and/or } \\
\text { vomiting }\end{array}$ & $\begin{array}{l}\text { Cesarean } \\
\text { section }\end{array}$ & IV & $\begin{array}{l}\text { palliative } \\
\text { therapy }\end{array}$ & Death & Alive \\
\hline 16 & 34 & 13 & $\mathrm{~N}$ & $\begin{array}{l}\text { abdominal } \\
\text { distention }\end{array}$ & Termination & III & Gastrectomy & Death & Death \\
\hline 17 & 36 & 14 & $\mathrm{~N}$ & $\begin{array}{l}\text { abdominal } \\
\text { pain }\end{array}$ & Termination & IV & Gastrectomy & Death & Death \\
\hline 18 & 37 & 15 & $\mathrm{~N}$ & $\begin{array}{l}\text { abdominal } \\
\text { pain }\end{array}$ & Termination & $\|$ & Gastrectomy & Death & Death \\
\hline 19 & 38 & 21 & $\mathrm{~N}$ & $\begin{array}{l}\text { abdominal } \\
\text { distention }\end{array}$ & Termination & IV & $\begin{array}{l}\text { palliative } \\
\text { therapy }\end{array}$ & Death & Death \\
\hline
\end{tabular}




\begin{tabular}{|cccccccccc|}
20 & 39 & 21 & N & $\begin{array}{l}\text { abdominal } \\
\text { distention }\end{array}$ & Termination & III & $\begin{array}{l}\text { palliative } \\
\text { therapy }\end{array}$ & Death & Death \\
\hline 21 & 40 & 19 & $N$ & $\begin{array}{l}\text { abdominal } \\
\text { distention }\end{array}$ & Termination & IV & $\begin{array}{l}\text { palliative } \\
\text { therapy }\end{array}$ & Death & Death \\
22 & 41 & 20 & $N$ & $\begin{array}{l}\text { abdominal } \\
\text { distention }\end{array}$ & Termination & IV & $\begin{array}{l}\text { palliative } \\
\text { therapy }\end{array}$ & Death & Death \\
\hline
\end{tabular}

Table 2. Clinicopathological Features of the Gastric Cancer in the two groups. 


\begin{tabular}{|c|c|c|c|}
\hline Clinicopathological feature & Case $(n=22)$ & Control(n=44) & P-value \\
\hline Age (year) & $32(26-41)$ & $33(27-45)$ & 0.873 \\
\hline Family history & $4(18.2 \%)$ & $7(15.9)$ & 0.991 \\
\hline Time from symptom to diagnosis (day) & $75.4 \rrbracket 28-139 \rrbracket$ & $64(27-201)$ & 0.712 \\
\hline Time from diagnosis to treatment (day) & $19(8.0-29.0)$ & $9(3-14)$ & 0.012 \\
\hline Initial presentation & & & 0.087 \\
\hline Abdominal pain & $6(27.3 \%)$ & $11(25 \%)$ & \\
\hline Nausea/vomiting & $3(13.6 \%)$ & $5(11.4 \%)$ & \\
\hline Dyspesia & $3(13.6 \%)$ & $16(36.4 \%)$ & \\
\hline melena & $1(4.6 \%)$ & $3(6.8 \%)$ & \\
\hline Metastatic symptoms & $9(40.9 \%)$ & $9(20.4 \%)$ & \\
\hline Tumor location & & & 0.004 \\
\hline Antrum & $7(31.8 \%)$ & $4(9.1 \%)$ & \\
\hline Corpus & $7(31.8 \%)$ & $32(72.7 \%)$ & \\
\hline Entier & $8(36.4 \%)$ & $8(18.2 \%)$ & \\
\hline Clinical or pathological stage & & & 0.231 \\
\hline I & $1(4.55 \%)$ & 0 & \\
\hline II & $1(4.55 \%)$ & $1(2.3 \%)$ & \\
\hline III & $2(9.1 \%)$ & $2(4.5 \%)$ & \\
\hline IV & $18(81.8 \%)$ & $41(93.2)$ & \\
\hline Treatment summary & & & 0.124 \\
\hline Gastrectomy & $5(22.7 \%)$ & $11(25 \%)$ & \\
\hline Chemotherapy & $5(22.7 \%)$ & $10(22.7 \%)$ & \\
\hline Best supportive care & $12(54.6 \%)$ & $23(52.3 \%)$ & \\
\hline Histological differentiation & & & 0.231 \\
\hline Adenocarcinoma poorly differentiated & $12(54.6 \%)$ & $21(47.7 \%)$ & \\
\hline Signet ring cell carcinoma & $10(45.4 \%)$ & $20(45.5 \%)$ & \\
\hline Mucinous carcinoma & 0 & $3(6.8 \%)$ & \\
\hline Overall survival (month) & $8(2.3-25.8)$ & $11(3.6-27.3)$ & 0.05 \\
\hline
\end{tabular}

